Игорь Иванович КАЛИГАНОВ 
DOI $10.31168 / 0436-7.24$

\section{ГЕОРГИЙ НОВЫЙ СОФИЙСКИЙ - МУЧЕНИК ЗА ВЕРУ, СОЖЖЕННЫЙ ТУРКАМИ ЗА ОТКАЗ ПРИНЯТЬ ИСЛАМ ${ }^{1}$}

\section{Аннотация:}

В статье рассказывается о болгарском юноше Георгии, казненном турками в 1515 г. в Софии за отказ принять ислам. Его почитание быстро распространилось на Балканах и столь же быстро проникло в русские земли посредством устной передачи сюжета: всего лишь через четверть века афонские монахи Прохор и Митрофан рассказали о трагической гибели мученика новгородскому архиепископу Макарию, и тот повелел священнику своей домовой церкви, иеромонаху Илье составить житие Георгия Нового, используя сведения странников. Спустя 10 лет этот софийский мученик был канонизован как общероссийский святой на московском Церковном Соборе 1549 г., и в этой связи псковский агиограф Василий-Варлаам написал проложное житие и службу страдальцу. Культ Георгия Нового получил исключительно широкое распространение в русских землях, сравнявшись по своему масштабу с культами других известных южнославянских святых, пустынножителя Ивана Рильского и архиепископа Саввы Сербского.

\section{Ключевые слова:}

Балканы, религиозная ассимиляция, мученичество, Георгий Новый, болгарская и русская версии житий и служб, особенности культа, исключительная известность в России.

Abstract: I.I. Kaliganov "George the New of Sofia: A martyr, Burned by the Turks for REFUSING TO ACCEPT ISLAM".

The article talks about the Bulgarian youth George, executed by the Turks in 1515 in Sofia for refusing to accept Islam. His veneration quickly spread to the Balkans and just as quickly penetrated the Russian lands through the oral transmission of the story: only a quarter of a century later Athonite monks Prokhor and Mitrophan spoke about the tragic death of the Martyr in Novgorod to Archbishop Macarius, and he told the priest of his home Church, hieromonk Iliah to make a Life of George the New using the information of the strangers. Ten years later, this Martyr of Sofia was canonized as an all-Russian Saint at the Moscow Church Council in 1549, and in this regard, the Pskov hagiographer Vasily-Varlaam wrote a short life and service to the sufferer. The cult of George the New was extremely widespread in Russian lands, equaling in scale the cults of other famous South Slavic saints, the hermit John of Rila and Archbishop Sava of Serbia.

\section{Keywords:}

The Balkans, religious assimilation, martyrdom, George the New, Bulgarian and Russian versions of lives and services, features of the cult, exceptional fame in Russia.

\footnotetext{
1 Работа выполнена при финансовой поддержке РФФИ (грант № 18-512-76004).
} 
Георгий Новый Софийский (1497ный турками 11 февраля 1515 г. в болгарском г. Средец (София) за отказ принять ислам и ставший широко известным не только на славянском православном юге, но и в русских землях.

Возникновение посвященных данному мученику агиографических произведений связано с Афонско-Константинопольской мартирологической традицией прославления мучеников за веру, пострадавших от завоевателей-турок, которые принуждали переходить в магометанство представителей порабощенных христианских народов на Балканах в конце XV-XIX вв. Одним из таких страдальцев стал и Георгий Новый Софийский. Историю жизни и мученичества этого героя подробно и вполне реалистично изложил софийский пресвитер Пейо, написавший житие подвижника и составивший ему службу. По сведениям книжника, Георгий родился в македонском г. Кратово, рано лишился отца и решил поискать счастья в Софии, надеясь не пропасть благодаря своей любимой

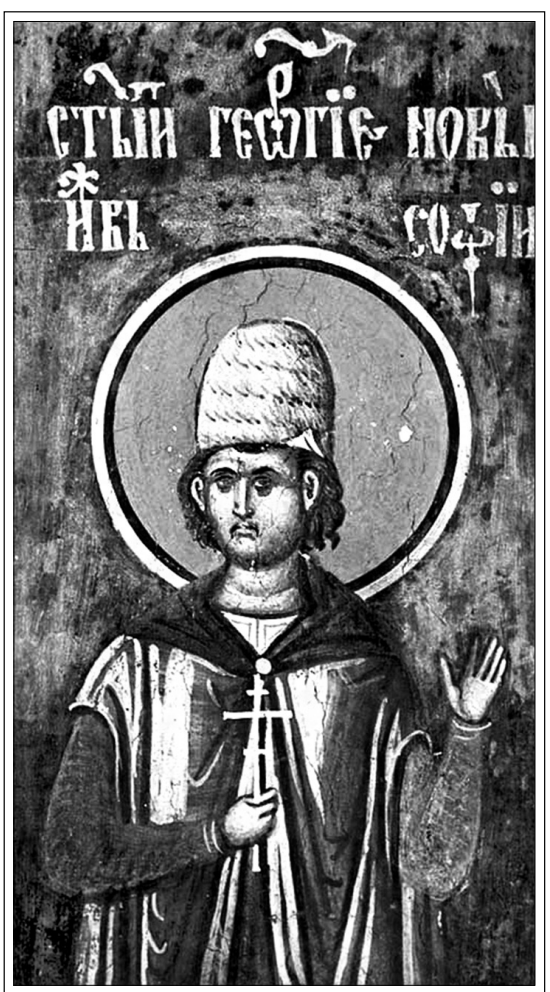

Георгий Новый Софийский.

Стенопись сербской Печской патриархии. 1561 г. профессии «златокузнеца», т.е. ювелира. Пейо приютил юношу и стал для него духовным отцом. Все шло хорошо, но внезапно подступила беда. Юный Георгий был необычайно хорош собою, и софийские турки стали склонять его к магометанской вере. Именно из-за этого и угрозы быть взятым в янычары он и бежал из родного города в Софию, но и здесь его поджидала аналогичная опасность. Укрепляемый в вере своим духовным отцом Георгий отбил все попытки турок прельстить его мнимыми достоинствами вероучения Магомета по сравнению с Христовым, и тогда те решили добиться своего насилием. Они оклеветали юношу перед мусульманским судьей, и Георгий был приговорен к пыткам за ложное обвинение в поношении Магомета. В течение нескольких дней продолжались допросы и истязание юноши, избежать которого можно было при условии принятия им ислама. Но Георгий твердо стоял во Христе, предпочтя ужасные мучения и жестокую казнь отказу от исконной веры.

Стойкость духа помогал ему крепить его духовный отец, автор жития пресвитер Пейо. В нарушение традиций житийных произведений он игра- 
ет в своем сочинении самую активную роль: уговаривает мусульманского судью проявить к Георгию снисходительность, призывает своего духовного сына не поддаваться на уговоры магометан сменить веру и пострадать за Христа. Роль Пейо не ослабевает в произведении на протяжении всего развития действия. Он проникает в толпу агарян, ведущую приговоренного к смерти Георгия к месту сожжения, организует похищение останков мученика из под носа у заснувших турецких стражников и хитростью добивается у мусульманского судьи разрешения на их торжественное захоронение в соборной церкви св. Марины, где сам служил. При описании событий Пейо приводит в тексте жития множество реалистических деталей, которые в агиографических памятниках авторы обычно опускают. Для достижения большей достоверности повествования он стремится передать логику поступков персонажей и подкрепить ее правдивыми, жизненными деталями. Так, например, свои наставнические беседы с юношей Пейо проводит в доме темничного стража, которого он хорошо знал и уговорил его организовать Эти встречи, а похищение останков юноши за мзду осуществляет по его поручению некий безымянный христианин, живший поблизости от места казни подвижника. В некоторых эпизодах жития использованы элементы натурализма, оказывающие сильное впечатление на читателя: перед тем, например, как окончательно ввергнуть Георгия в огонь, турки трижды предварительно испытывают мученика жаром пламени, пока все его тело не покрывается волдырями от ожогов.

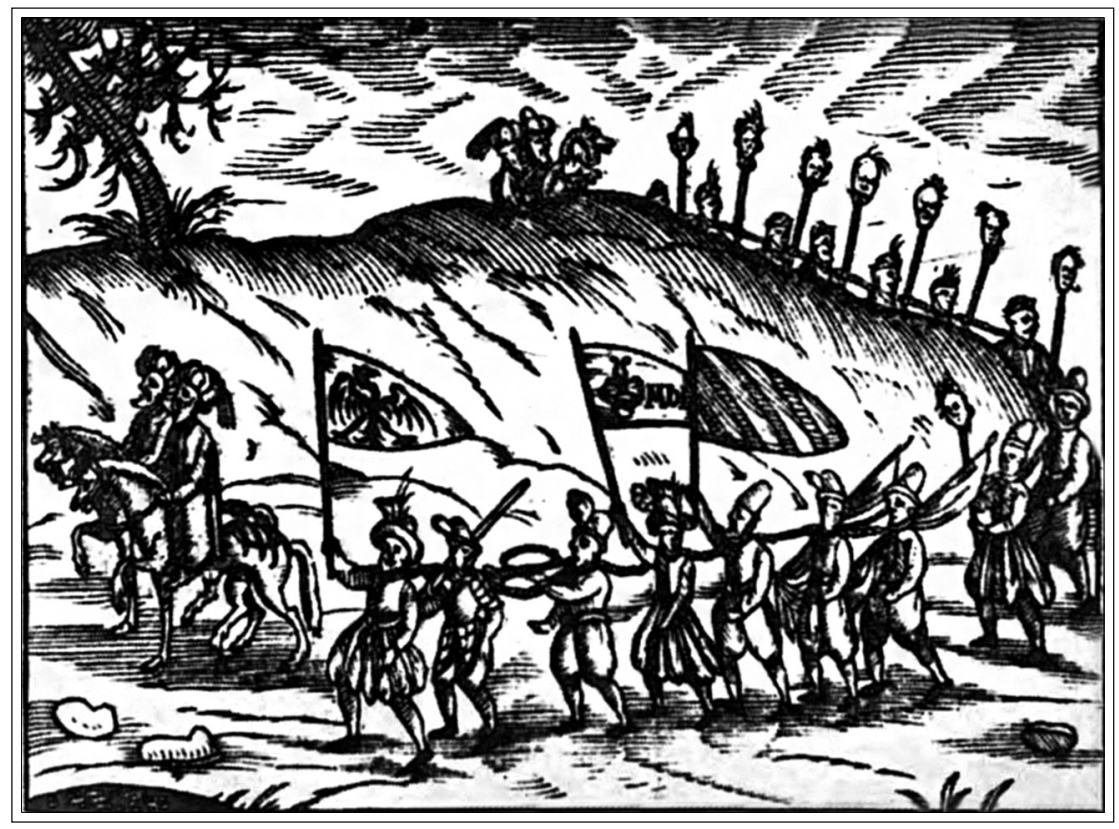

Турки уводят пленных христиан в рабство.

Гравюра XVIII в. 
Георгий Новый Софийский быстро стал на Балканах одним из самых популярных мучеников за веру, пострадавших от турок за отказ перейти в ислам. Написанные пресвитером Пейо житие и служба Георгию Новому распространились в полутора десятках списков XVI-XIX вв. не только в Cофии, но и в родном городе мученика Кратово, Белграде, Сараево и афонском Хиландарском монастыре. Частицы мощей юного страдальца хранились как святыни в Софии, Драгалевской пригородной обители, в сербских монастырях Студеница, Хиландар, Великая Ремета и Дечаны. Появились в тот период на Балканах и многочисленные иконы и стенописи Георгия Нового, древнейшие из которых датируются 30-ми годами XVI-XVII вв. и находятся в церкви св. Николая в Топлице, афонском Хиландарском монастыре, Печской патриархии, обителях Студеница и Ломница.

Весть о сожжении софийского подвижника через четверть века после его гибели принесли в Россию монахи пресвитер Прохор и Митрофан, насельники Зографского монастыря св. Георгия Победоносца на Афоне. Они прибыли в русские земли в 1539 г. «милостыни ради» (т.е. для сбора пожертвований) и, побывав в Новгороде и Пскове, рассказали о мученической смерти Георгия Нового новгородскому архиепископу Макарию - будущему Московскому митрополиту и наставнику Ивана Грозного. Эта история вызвала у того неподдельный интерес, и он повелел пресвитеру своей домовой церкви, иеромонаху Илье составить житие на основе устных сведений афонских монахов. К сожалению, созданное им житие нельзя считать надежным историческим источником. Прохор и Митрофан проездом по пути в Московское государство явно находились в Софии недолгое время, свидетелями смерти Георгия Нового не были и располагали лишь теми сведениями, которые могли почерпнуть от местных софийских мирян и иерархов. Именно тогда в их сознании возникла путаница и смешение реальных данных о жизни и казни Георгия Нового с фактами подобного рода, связанными с кончиной другого местного тезоименитого страдальца, которого позднее назвали Георгием Новейшим. Этот подвижник, вероятно, принял кончину в середине 30-х годов XVI в. незадолго до появления в Софии афонских странников Прохора и Митрофана. Житие и служба ему составлены не было - узнать о нем можно было лишь из местных противоречивых легенд.

Вероятно, именно по этой причине многие фактические данные о жизни и смерти Георгия Нового в житиях двух пресвитеров - софийского Пейо и новгородского Ильи - столь разительно не совпадают. У первого - родителей Георгия звали Димитрий и Сарра, у второго - Иоанн и Мария; Пейо свидетельствует о том, что мученик родился в Кратово, а Илья говорит, что родным городом Георгия была София; в первом произведении констатируется, что юноша погиб в возрасте 18 лет, а во втором - что тот был старше на семь лет. Отличаются также у двух авторов дни и месяцы страдания подвижника: Пейо сообщает о зиме - 11 февраля, а Илья пишет о конце весны - 26 мая. Не располагая точными данными о жизни софийского мученика, русский автор заполнил отсутствие фактической канвы 
агиографической топикой и избрал для себя в качестве литературного образца одно из риторических произведений известного болгарского писателя Григория Цамблака: житие Иоанна Нового Белгородского - греческого торговца, принявшего смерть от татарских язычников в XIV столетии в Аккермане. Из него Илья позаимствовал многие пассажи, вставляя их в текст своего сочинения в подходящих местах, особенно когда чувствовал затруднение из-за незнания конкретных фактов из жизни Георгия Нового. Но это нельзя ставить автору в вину - приемы компиляции при работе средневековых агиографов были очень распространены и считались делом не зазорным, а похвальным, тем более, если пассажи заимствовались у авторитетных мастеров слова.

При всей кажущейся малой ценности произведения пресвитера Ильи из-за обилия в нем компилятивного материала и фактических неточностей, недооценка его, как очень важного памятника русской истории и литературы, была бы несправедливой. Во-первых, он является важным историческим источником о положении южных славян под иноземным игом в период правления турецкого султана Селима I (1512-1520), прозванного подданными «Явуз» - Жестокий, Грозный ${ }^{2}$ Сведения об этом содержатся не в основном тексте жития, а во вводной его части, в которой, со слов афонских монахов, Илья подробно рассказал о насильственных наборах на славянском юге наиболее сильных и красивых мальчиков в янычары, о совершении над ними обряда обрезания, воспитании в духе мусульманского фанатизма и превращении в главную ударную силу войска султана, которая используется для завоевания христианской Европы. Кроме того, в Московском государстве Георгий Новый превратился в главный символ мученика на Балканах, казненного магометанами за отказ принять ислам. Его история была близка и понятна в русских землях, из которых в результате татарских набегов из Казани, Астрахани и Крыма в полон уводились десятки тысяч людей, и многих из них обращали в ислам. На Стоглавом соборе в 1551 г. был принят подушный налог для выкупа русских полоняников из плена. Почти в это же время были создано житие русского мученика Ивана, уведенного в полон в Казань и погибшего там за стойкость во Христе и нежелание перейти в магометанство. Именно это сходство ситуаций на Балканах и славянском востоке придало необычайную популярность литературным памятникам, созданным в честь Георгия Нового на Руси.

Помимо жития Георгия Нового пресвитера Ильи, известный псковский агиограф Василий-Варлаам в связи с церковными Соборами 1547 и 1549 гг. написал службу и проложное житие софийского мученика. В службе, как и в пространном житии у пресвитера Ильи, у него присутствуют много-

2 В статье о Георгии Новом, помещенной в Православной энциклопедии, ошибочно говорится, что мученик пострадал при турецком султане Селиме II, который на самом деле начал править через полвека после гибели мученика: с 1566 по 1574 г. См. Typuлов AА., Темелски Хр. Георгий Новый Кратовский // Православная энциклопедия. Т., ХІ. M., 1997. C. 69. 


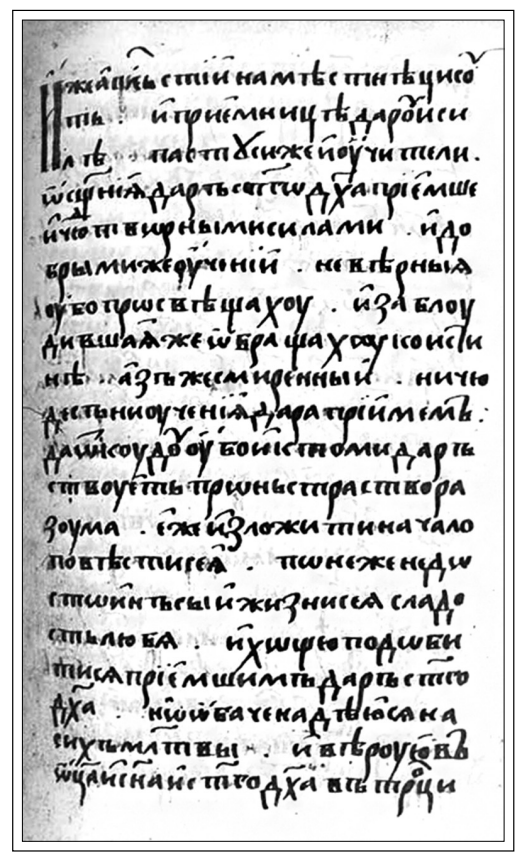

Начало русского жития Георгия Нового.

Автограф новгородского пресвитера Ильи. 1539 г.

численные компиляции из аналогичного жанрового произведения в честь Иоанна Нового Белгородского, написанного Григорием Цамблаком. Отдельные песнопения из службы Георгию Новому еще в конце 50-х - начале 60-х годов XVI в. распели русские певчие, снабдив тексты знаменной музыкальной нотацией.

В целом русская рукописная традиция памятников о Георгии Новом Софийском XVI-XIX вв. оказалась гораздо богаче аналогичной традиции на Балканах. В ней представлено более 30 списков пространного жития Ильи, 17 списков проложного жития Василия-Варлаама, шесть отрывков из него, один список краткой анонимной редакции памятника, 15 списков составленной Василием-Варлаамом службы софийскому страдальцу и многочисленные стихиры и славы из нее, помещенные в 11 певческих сборниках с нотацией. Различные варианты русского жития Георгия Нового вошли в крупнейшие русские рукописные своды XVI - XVII вв.: Царский комплект Великих Четьих Миней митрополита Макария и в Минеи священника Иоанна Милютина, которые он составил вместе со своими сыновьями в 1646-1654 гг. Взлет известности софийского мученика в России произошел после включения с 1622 г. службы Георгию Новому в московские старопечатные издания служебных миней и проложного жития мученика в начавшие издаваться в Москве с 40-х годов XVII в. старопечатные прологи. Последнее вошло и в самое большое старопечатное не богослужебное издание «Жития русских святых» митрополита Димитрия Ростовского, которое было осуществлено в типографии Киево-Печерской Лавры в 1689-1705 гг. и неоднократно затем переиздавали.

По степени известности в русских землях Георгий Новый Софийский приближался к другим наиболее почитаемым южнославянским подвижникам: Ивану Рильскому и Савве Сербскому, культ которых проник на славянский северо-восток значительно раньше. Изображений мученика известно сравнительно немного: древнейшие из них расположены на иконах «таблетках» 60-х - 70-х годов XVII в. и на относящейся ко второй половине XVII в. стенописи Воскресенского собора в волжском г. Борисоглебске. Большее почитание в России приобрели частицы мощей Георгия Нового, привезенные в Москву с Афона или славянского юга в конце XVI в. - начале XVII в. Они были помещены в три креста-мощевика работы кремлев- 
ских мастеров и предназначались для храма Благовещения - находящейся в Кремле домовой церкви русских царей, и как подарки царевичу Алексею Михайловичу по случаю его крещения 22 марта 1629 г. в кремлевском Чудовом монастыре. Последние два креста были изготовлены по заказу отца царевича царя Михаила Федоровича и его бабушки великой княгини Марфы Ивановны и представляли собой драгоценные произведения искусства.

Имена Георгия Нового, его мучителя «безбожного царя Селима Турскаго» и название болгарского г. Средца, в котором был сожжен мученик, звучали во время богослужений в Новгороде и Пскове, Москве и Ярославле, на русском Севере, далеких Соловках, в Сибири и других уголках русской земли. Это заставляло прихожан задумываться о томящихся в турецкой неволе южных славянах, наполняло сердца молящихся сочувствием к ним и наводило на мысль, что невольников следует освободить.

\section{ЛИТЕРАТУРА}

Богдановић Д. Житије Георгија Кратовца // Зборник историје књижевности.

Одељење језика и књижевности. САНУ. Београд, 1976. Књ. 10.

Динеков П. Софийски книжовници от XVI в. Часть I. Поп Пейо. София, 1939.

Калиганов И.И. Георгий Новый у восточных славян. Москва, 2000.

\section{СПИСОК ИЛЛЮСТРАЦИЙ}

1. Турки уводят христиан в плен. Гравюра XVIII в.

2. Подготовка христианских мальчиков для турецкого янычарского корпуса. Гравюра С. Швейгера. 1577 г.

3. Храм св. Софии (VI в.), подле которого в 1515 г. сожгли Георгия Нового Софийского за отказ принять ислам.

4. Св. Георгий Новый Софийский. Стенопись в сербской Печской патриархии. 1561 г.

5. Св. Георгий Новый Софийский и св. князь Лазарь Сербский. Икона афонского Хиландарского монастыря. 1677 г.

6. Зографский монастырь на Афоне.

7. Крестовая (владычная) палата новгородского Кремля, в которой служил пресвитер Илья - автор русского жития Георгия Нового Софийского.

8. Лист древнейшего текста русского жития Георгия Нового Софийского. Автограф новгородского пресвитера Ильи. Москва, ОР ГИМ, собр. Е.В. Барсова, № 313. Л. 525. 1539 г.

9. Лист древнейшего текста русской службы Георгию Новому Софийскому. Автограф псковского пресвитера Василия-Варлаама. ОР РГБ, ф. 98 (собрание Е.Е. Егорова), № 938. Л. 297 об. Конец 40-х годов XVI в.

10. Храм Рождества Христова на Шипке. Часть мемориального комплекса в честь освобождения Болгарии от османского ига. 1885-1902 гг.

11. Св. Георгий Новый Софийский. Стенопись 50-х годов ХХ в. в храме Рождества Христова на Шипке. 